DOI 10.14746/ps.2015.1.32

\title{
Daisuke Akimoto, Japan As a 'Global Pacifist State': Its Changing Pacifism and Security Identity, Peter Lang, Berno 2013, ss. 281.
}

O japońskim pacyfizmie napisano już wiele, zarówno w literaturze japońskiej, jak i światowej. Wraz z objęciem urzędu premiera przez Shinzō Abe zagadnienie to powróciło na wokandę, pod postacią koncepcji ,aktywnego pacyfizmu” i planów zmiany polityki bezpieczeństwa Japonii. Dało to asumpt do kolejnej analizy japońskiej historii pacyfizmu, choć niełatwo o nowe konkluzje w tym temacie. Japan As a 'Global Pacifist State': Its Changing Pacifism and Security Identity autorstwa Daisuke Akimoto jest swego rodzaju nowością $\mathrm{w}$ tej kategorii - monografia wprowadza m.in. nowe tezy badawcze do teorii japońskiego pacyfizmu i analizuje japońską tożsamość bezpieczeństwa pod kątem teorii stosunków międzynarodowych. O nowatorskim podejściu do tematu świadczy m.in. analiza korelacji pomiędzy ewolucją cech japońskiego pacyfizmu a zmianami w japońskiej tożsamości bezpieczeństwa, co, jak podkreśla Autor we wstępie książki, dotychczas nie znalazło wyjaśnienia w literaturze. Dodatkowo, do zbioru pojawiających się na przestrzeni ostatnich dekad odmian japońskiej tożsamości bezpieczeństwa, Autor wprowadza definicję tożsamości „globalnego państwa pacyfistycznego” (ang. global pacifist state). W opinii D. Akimoto koncepcja ta będzie dominantą japońskiej tożsamości bezpieczeństwa w nadchodzących latach.

Książka jest pierwszą monografią D. Akimoto, opartą o wcześniejszą pracę doktorską, i stanowi opis przemian japońskiego pacyfizmu oraz ich konsekwencji dla japońskiej tożsamości bezpieczeństwa. Tematem przewodnim jest historyczny proces ewolucji japońskiego pacyfizmu z „negatywnego” na „pozytywny”, w odpowiedzi na zmiany w układzie sił w Azji i na świecie. Głównym celem monografii jest odpowiedź na pytania: co doprowadziło do powyższej zmiany i w jaki sposób przemiana ta wpływa na japońską tożsamość bezpieczeństwa. Autor rozważa powyższe zagadnienia chronologicznie, w płaszczyznach wyznaczonych przez kilka historycznych okresów lub wydarzeń. Są to kolejno: lata 1945-1990, udział Japońskich Sił Samoobrony w misjach pokojowych ONZ, amerykańska wojna $\mathrm{z}$ terroryzmem oraz plany rewizji konstytucji Japonii. Autor przedstawia też analizę poszczególnych modeli japońskiej tożsamości bezpieczeństwa w odniesieniu do nurtów naukowych w teorii stosunków międzynarodowych: liberalizmu klasycznego, neoliberalizmu, realizmu klasycznego, neorealizmu oraz konstruktywizmu. Proponuje zatem następujące modele: 1) Japonia jako państwo pacyfistyczne (liberalizm klasyczny); 2) Japonia jako aktywny członek sił pokojowych ONZ (neoliberalizm); 3) Japonia jako „normalne” państwo (klasyczny realizm); 4) Japonia jako sojusznik USA (neorealizm). Jak wyjaśnia D. Akimoto, żadna z teorii stosunków międzynarodowych sama w sobie nie może stanowić wyjaśnienia dla japońskiej tożsamości bezpieczeństwa, a więc Autor proponuje podejście konstruktywistyczne - analiza powinna być kompleksowa i eklektyczna. Innymi słowy to, co może być wyjaśnione za pomocą teorii realistycznych (np. dążenie Japonii do „,normalizacji” siły militarnej) musi być uzupełnione przez teorie - w danym przypadku - liberalistyczne (np. angażowanie się w misje pokojowe ONZ).

Recenzowana monografia składa się z pięciu rozdziałów z wyróżnionym wstępem i podsumowaniem. Każdy z rozdziałów omawia jeden z pięciu okresów i wydarzeń historycznych, które w sposób znaczący wpłynęły na kształtowanie się kolejnych modeli japoń- 
skiej tożsamości bezpieczeństwa. Jak już nadmieniono powyżej, mamy tu kolejno: 1) lata 1945-1990; 2) udział Japońskich Sił Samoobrony w misji pokojowej ONZ w Kambodży; 3) udział Japońskich Sił Samoobrony w misji pokojowej ONZ w Timorze Wschodnim; 4) Japonia jako sojusznik USA i odpowiedź na amerykańską wojnę z terroryzmem oraz 5) plany rewizji konstytucji Japonii. Dodatkowo w każdym z rozdziałów znajdziemy omówienie japońskiej tożsamości bezpieczeństwa z perspektywy głównych nurtów teorii stosunków międzynarodowych. Książka opatrzona jest pokaźną bibliografią w języku japońskim i angielskim, z uwzględnieniem najważniejszych dzieł dotyczących teorii stosunków międzynarodowych.

Wstęp do monografii stanowią rozważania teoretyczne na temat modeli japońskiej tożsamości bezpieczeństwa. Autor dokonuje dość szczegółowej analizy literatury przedmiotu. W sposób wyraźny podkreśla również cel pracy oraz wyszczególnia hipotezy badawcze. Głównymi celami Autora jest zarys przyczyn pojawienia się ,pozytywnego pacyfizmu”, określenie perspektyw dla normalizacji militarnej Japonii oraz analiza wpływu ,pozytywnego pacyfizmu" na japońską tożsamość bezpieczeństwa. Niniejsza część pracy zawiera również uzasadnienie celowości teoretycznego podejścia do tematu japońskiej tożsamości bezpieczeństwa oraz opis metodologii przeprowadzonych badań.

Rozdział pierwszy przedstawia zarys historyczny japońskiej polityki bezpieczeństwa w latach 1945-1990. D. Akimoto definiuje genezę ,negatywnego pacyfizmu” oraz wyjaśnia jego wpływ na politykę bezpieczeństwa i tożsamość bezpieczeństwa od wczesnych lat powojennych do zakończenia zimnej wojny. Historia „negatywnego pacyfizmu” przedstawiona jest tu w oparciu o analizę faktograficzną - punktami odniesienia są tak ważne wydarzenia, jak: okres amerykańskiej okupacji, uchwalenie japońskiej konstytucji, wybuch wojny koreańskiej, zawiązanie sojuszu japońsko-amerykańskiego w 1951 r. czy wojna w Wietnamie. W odczuciu recenzentki Autor słusznie wyznacza ramy czasowe w oparciu o ówczesny charakter japońskiej polityki bezpieczeństwa - od lat powojennych po koniec polityki zimnowojennej i rozpoczęcie pierwszej wojny w Zatoce Perskiej. Dwa ostatnie wydarzenia stały się bowiem przyczynkiem do rewizji dotychczasowej polityki bezpieczeństwa w Japonii, a więc redefinicji znaczenia Sił Samoobrony i sojuszu z USA oraz do reinterpretacji pacyfistycznej konstytucji. Jak zaznacza Autor, powyższa cezura czasowa wyznacza również okres trwania ,państwa pacyfistycznego" (ang. pacific state) jako dominanty w japońskiej tożsamości bezpieczeństwa.

Rozdziały drugi i trzeci stanowią analizę studiów przypadku uczestnictwa Japońskich Sił Samoobrony w misjach pokojowych ONZ w Kambodży i Timorze Wschodnim. Autor szczegółowo nakreśla tło historyczne i sytuację polityczną w tych państwach oraz wskazuje znaczenie uczestnictwa Japonii w obu misjach dla zmiany japońskiej tożsamości bezpieczeństwa. Według D. Akimoto, uchwalenie w 1992 r. Prawa o współpracy [z ONZ] w operacjach pokojowych (ang. Peace Cooperation Law), a następnie udział Sił Samoobrony w operacjach ONZ sprawił, że Japonia z państwa pacyfistycznego (pacifist state) stała się członkiem międzynarodowych sił pokojowych (peacekeeper). To z kolei, jak zauważa Autor, wskazuje na początki ,pozytywnego pacyfizmu” w Japonii i podjęcie działań w kierunku militarnej normalizacji państwa.

Rozdział czwarty analizuje odpowiedź ówczesnego rządu japońskiego oraz reakcję opinii publicznej na zamachy terrorystyczne w USA z 11 września 2001 r. i na amerykańską wojnę $z$ terroryzmem. Autor opisuje w jakim stopniu sytuacja wewnętrzna i zewnętrzna wpłynęły na decyzje rządu o wysłaniu japońskich okrętów na Ocean Indyjski i Sił Samo- 
obrony na wojnę w Iraku. W opinii Autora, w tym okresie nastąpiła ponowna zmiana japońskiej tożsamości bezpieczeństwa - z sojusznika USA Japonia stała się międzynarodowym inicjatorem budowania pokoju (peacebuilder).

Na rozdział piąty składają się rozważania na temat rewizji konstytucji i ewentualnych konsekwencji dla japońskiego pacyfizmu i tożsamości bezpieczeństwa. Autor dodatkowo wprowadza tytułową koncepcję Japonii jako „światowego państwa pacyfistycznego” (ang. global pacifist state). Jak wyjaśnia A. Daisuke, koncepcja ta stanowi połączenie elementów tożsamości państwa pacyfistycznego („negatywny pacyfizm”) i Japonii angażującej się w operacje ONZ (,pozytywny pacyfizm”). W jego przekonaniu, mimo że japońska tożsamość bezpieczeństwa „dryfuje” pomiędzy wizerunkami państwa pacyfistycznego, sojusznika USA, członka sił pokojowych ONZ i ,,normalnego” państwa, tożsamość ,światowego państwa pacyfistycznego" jest tu cechą nadrzędną. Według tezy Autora to właśnie ta koncepcja będzie determinować charakter japońskiej polityki bezpieczeństwa w nadchodzących latach niezależnie od sytuacji wewnętrznej i międzynarodowej.

Zwieńczeniem monografii jest podsumowanie rozważań teoretycznych dotyczących japońskiej tożsamości bezpieczeństwa oraz weryfikacja głównych hipotez badawczych. Autor dokonuje prognozy ewolucji japońskiej tożsamości bezpieczeństwa i ponownie podkreśla stwierdzenie, że jej dominantą w najbliższych latach będzie koncepcja ,globalnego państwa pacyfistycznego” oparta zarówno na elementach „,negatywnego”, jak i ,pozytywnego pacyfizmu".

Z uwagi na afiliację Autora ${ }^{1}$ może pojawić się obawa o obiektywizm naukowy w badaniach dotyczących japońskiego pacyfizmu, uczestnictwa Japońskich Sił Samoobrony w misjach pokojowych ONZ oraz w kwestii tak dyskusyjnej, jak rewizja konstytucji. Książka napisana jest jednak obiektywnie, z uwzględnieniem argumentów i stanowisk badaczy japońskiej polityki z różnych kręgów. Autor co prawda kilkakrotnie wspomina o roli, jaką odegrała partia Kōmeitō w przemianie japońskiej tożsamości bezpieczeństwa, jednak w opinii recenzentki jest to akurat zaletą niniejszej publikacji, choćby dlatego, iż działalność tej partii bywa opisywana w literaturze dość pobieżnie. Książka jest przede wszystkim omówieniem ewolucji japońskiej polityki i tożsamości bezpieczeństwa, kształtujących się na tle najważniejszych dla Japonii wydarzeń od czasów powojennych do współczesności. Monografię cechuje dość szeroka perspektywa badawcza - wnikliwa analiza tła historycznego i politycznego poszczególnych okresów japońskiej polityki bezpieczeństwa jest wartościowym studium historii japońskiego pacyfizmu. Dużym walorem pracy, również z językowego punktu widzenia, są znajdujące się w tekście tłumaczenia fragmentów japońskich ustaw i publicznych wypowiedzi japońskich polityków. Na dodatkowe wyróżnienie zasługuje również konceptualizacja japońskiego pacyfizmu na podstawie wybranych nurtów naukowych: realizmu klasycznego, neorealizmu, liberalizmu klasycznego, neoliberalizmu oraz konstruktywizmu. Tego typu rozważania teoretyczne z pewnością stanowią o oryginalności monografii, choć dla teoretyków stosunków międzynarodowych mogą one nie wyczerpywać tematu. Niemniej jednak Japan As a 'Global

1 Akimoto Daisuke jest obecnie adiunktem na Uniwersytecie Sōka w Tokio. Uniwersytet ten został założony z inicjatywy Sōka Gakkai - organizacji buddyjskiej, której członkowie byli również założycielami partii Kōmeitō. Choć partia już w latach 70. oficjalnie oświadczyła, że działa niezależnie od organizacji, członkowie Sōka Gakkai nadal aktywnie działają w partii. Inne publikacje D. Akimoto wskazują na zainteresowanie Autora kwestiami związanymi z Kōmeitō. 
Pacifist State': Its Changing Pacifism and Security Identity jest ciekawym i rzetelnym opracowaniem tematyki współczesnego pacyfizmu w Japonii. Ze względu na interdyscyplinarny charakter i obszerne zestawienie anglojęzycznych i japońskojęzycznych materiałów źródłowych, recenzowana publikacja będzie z pewnością użyteczna zarówno dla politologów, jak i japonistów.

Paulina WARCHOŁ

Poznań 